International Journal of Current Microbiology and Applied Sciences

ISSN: 2319-7706 Volume 10 Number 12 (2021)

Journal homepage: http://www.ijcmas.com

\title{
Diallel Analysis of Severity Score and Defoliation Percent of Late Leaf Spot (Cercosporidium personatum) [Berk.and Curtis] Deighton]) on Peanut (Arachis hypogaea $\mathrm{L}$ )
}

\author{
Neya Bawomon Fidèle ${ }^{1 *}$, Thio Ibié Gilles ${ }^{2}$, Dabire Tobdem Gaston ${ }^{1}$, Nana \\ Toundwensida Abel ${ }^{1}$, Koita Kadidia ${ }^{3}$, Zagre M'BI Bertin ${ }^{2}$ and Sankara Philippe ${ }^{4}$
}

${ }^{1}$ Université Nazi BONI/Centre Universitaire de Gaoua 01, P.O Box 1091, Bobo-Dioulasso 01, Burkina Faso.

${ }^{2}$ Institut de l'Environnement et de Recherches Agricoles (INERA) 01, P.O Box 476

Ouagadougou 01, Burkina Faso.

${ }^{3}$ Université Joseph KI-ZERBO / UFR Science de la Vie et de la Terre 03 P.O Box 7021

Ouagadougou 03, Burkina Faso.

${ }^{4}$ Université Aube Nouvelle 06 P.O Box 9283 Ouagadougou 06, Burkina Faso.

*Corresponding author

Keywords

Late leaf spot, heritability, diallel, percent defoliation, severity score

\section{Article Info}

Received: 08 November 2021 Accepted: 30 November 2021 Available Online: 10 December 2021
Peanut late leaf spot (Cercosporidium personatum) [Berk.and Curtis] Deighton]) caused yield losses worldwide. An analysis of the genetic effects of resistance to late leaf spot on peanut in a full diallel was performed using Griffing (1956) and Hayman (1954) methods. The objective of the study was to analyse the genetic potential of six parental lines and to determine through severity score and percent defoliation how resistance was transmitted to their descendants. The study found that the severity score gives a broad-sense heritability of $90.2 \%$ and a narrow-sense heritability of $70.8 \%$. Defoliation indicated broad-sense heritability of $39 \%$ and a narrow-sense heritability of $40.6 \%$. Graphical analysis revealed that resistance to the disease may arise from a complex of dominant and recessive genes. GCA, SCA and Reciprocal Combining Effect was highly significant for the severity score and no significant for defoliation. Additivity have a preponderant influence on the resistance gene expression and severity score appear to be first choice trait in the diallel analyzes for resistance. This severity score better reflected resistance it was more heritable and could be a trait of choice in the breeding strategy to improve resistance to late leaf spot. NAMA, PC79-79, GM656 could be recommended in hybridization programs aimed at improving resistance to late leaf spot. 


\section{Introduction}

In the context of climate change, it is necessary to go beyond phenotypic knowledge in peanuts (Arachis hypogaea L.) disease research. Indeed, knowledge on genome would make this research more efficient. Genomic selection (GS) is an emerging approach to increase selection intensity, accuracy, and genetic gains in breeding program for improving complex polygenic traits Chaudhari, S. et al., (2019). The designation of an International Year of legumes (AIL) (A/RES/ 68/231)FAO (2016) provides an opportunity to recognize the role of legumes including peanuts in the global diet. This confirms the need to promote the contribution made by legumes such as peanut to health, nutrition and sustainability. However, Phytosanitary problems are among the main factors hampering peanuts production. Globally, late leaf spot (LLS), a foliar fungal disease is one of the most important biotic Shokes et al., (1997). Wankhade, et al., (2021) constraint in peanut production. The leaves are very essential in carrying out photosynthesis and their poor condition can compromise the vegetative cycle of the plant and its yield. Early and late leaf spot are two devastating diseases of peanut (Arachis hypogaea L.) worldwide. Denwar, N. N. et al., (2021). Late leaf spot (Cercosporidium personatum)[Berk. and Curtis] Deighton]) disease is yield-limiting biotic stress in peanut production. Peanut is one of the most important crops where research into the genetic traits is essential for plant improvement Neya, et al., (2017). Therefore, creation of new varieties requires that any breeding program uses parental lines which allowed best combinations for resistance to pest. This creation of new varieties adapted to the growing conditions is the main role of the breeder in the system of agricultural research Faye, (2010). The leaf spot diseases instead reduce the total photosynthetic surface area of the leaves Singh, et al., (2011) which hinders the overall development of the plant; constitute a stimulant for the area of abscission of the leaflet, which causes the leaves to drop, Taita et al., (2005). Among the diseases, LLS, caused by (Cercosporidium personatum) [Berk. and Curtis] Deighton]) is known to be one of the most destructive disease. It produces lesions on leaves, stem, petioles and pegs and causes premature leaf defoliation Wankhade, et al., (2021). Is resistance to LLS an inheritable trait? Are there genotypes capable of conferring resistance to late leaf spotin peanuts? It therefore appears necessary to carry out a genetic analysis through a diallel to determine the heritability of resistance to LLS and contribute to identify the best combinations for hybridization programs. Among the biometric analysis methods, the diallel has been used in the analysis of the genetic effects of two components of resistance. The objective of the study was to analyse the genetic potential of six parental lines and to determine through severity score and percent defoliation how these two components of resistance are transmitted to their descendants. For this reason, it will specifically involve (i) screening peanuts entries from a full diallel crosses for resistance to late leaf spot (ii) determining the heritability of peanuts resistance to late leaf spot through severity score and percent defoliation, (iii) identify the best genotypes that could be recommended in hybridization programs aimed at improving peanuts for disease resistance.

\section{Materials and Methods}

\section{Area of study}

This study took place in Hauts-Bassins region (Burkina Faso), which is the second wettest region in the country after Cascades' region. The average rainfall is between 1000 and 1200 
mm per year however very irregular with heavy rains during the months of August and September.

\section{Experimental site}

The experiment was conducted in the National Institute for Agronomic Study and Research (INERA) in Farakoba (Bobo-dioulasso). This site is located at longitude $04^{\circ} 20 \mathrm{~W}$ and latitude $11^{\circ} 06 \mathrm{~N}$ (Figure.1).

Average temperatures are around $20^{\circ} \mathrm{C}$ in the cold season and $35^{\circ} \mathrm{C}$ in the hot season with a relative humidity of $80 \%$ during the rainy season. The climate is sudanese, characterized by a fairly long rainy season, starting in AprilMay and ending in November. The soils are characterized by sedimentary materials containing quartz, kaolin clay, iron, and sometimes alumina. These are acidic soils with a $\mathrm{pH}$ varying between 5 and 5.5 and with low chemical potential.

\section{Plant material}

Six shorts to medium cycle varieties with contrasting susceptibility levels to late leaf spot were used to achieve a complete diallel cross (Table.1). This resulted in the first F1 generation of 30 hybrids and six inbreeding which we refer to as "entries" (Table 2). GM656 is an introgression line of wild species.

It was obtained by Dr. Charles Simpson according to the following scheme: (Florunner x TxAG-6) BC3F3: 6 (C. E. Simpson, 1991; Simpson et al., 1993). The Virginia type PC79-79 is from ISRA-CNRA in Senegal, the CN94C and Spanish type SH470P are from INERA-Burkina. NAMA and AS are local varieties. The characteristics of these parents of the diallel are given in Table I. The F1 generation was tested at the Farakoba site in Hauts-Bassins region.

\section{Diallel analysis}

Griffin's and Hayman's models were used; these are two complementary classical methods that were used to interpret the data from diallel analysis for heritability. Griffing's method Griffing (1956) allows the detection of general (GCA) and Specific Combining Ability (SCA). The data processing by this model makes it possible to give information on the GCA and SCA thus giving information respectively on the additive and dominance effects. The method of Hayman (1954) lets estimate the different genetic components of the trait and the various parameters, such as additivity, dominance, reciprocal effects, heterosis and heritability

\section{Experimental screening design}

The experimental device is a completely randomized three-repeat Fischer block. Each repetition of 36 entries with six selfpollination include two sub-blocks of eighteen entries. The distance between two consecutive repetitions is one meter and between two subblocks 0.5 meter. Sowing is carried out flat at the rate of one seed per pocket.

\section{Evaluation of Late Leaf Spot Severity}

Late leaf spot severity rating scale given by Subrahmanyam, et al., (1995) was used. The disease severity was based on 1 to 9 scale, where the score from 1 to 3 are considered as resistant individuals; the score from 4 to 6 are considered as moderately resistant/moderately susceptible (tolerant) individuals and the score from 7 to 9 are considered highly susceptible individuals. It is a visual rating scale ranging from 1(no disease) to 9 (plant dead). The incidence of late leaf spot on the entries is evaluated on all the elementary plots per entry. Notes are taken every two weeks Ouedraogo, M. et al., (1994) from the 30th day after sowing, until harvest. 


\section{Defoliation percent calculation}

Defoliation of peanuts plants due to late leaf spot is leaf drop from peanuts plants; it is expressed as a percentage. It is assessed on the day of harvest, therefore at the stage of maximum leaf lost. Thus, on each row, the measurement was taken on the average of the main stems of three plants chosen at random, excluding the extreme plants. On each stem we count the number of fallen leaves and the total number of leaves (absent and present). The percentage of defoliation is equal to the ratio between the number of fallen leaves and the total number of leaves reduced to 100 .

$$
\% D F=\frac{N b r \text { fallen leaves }}{\text { Total } \mathrm{N} b r \text { of leaves }}
$$

\section{Data analysis}

The data were analyzed with the DIAL 98 software. This software allowed us to estimate the genetic parameters of each component of resistance to late leaf spot (severity score and percent defoliation), and to be able to assess the General (GCA) and Specific (SCA) Combining Ability. The analysis of variance and correlation was carried out with Minitab 18. The graphical analysis was carried out with the software DIALLEL. The results have been expressed in the form of tables and figures.

\section{Results and Discussion}

Analysis of variance of 36 F1 entries screening for resistance to late leaf spot

The average performance of the 36 entries is shown in (Table 3). These results indicate the existence of a very highly significant difference $(\mathrm{P}=0.0001)$ for the severity score of the disease and no significant for defoliation $(\mathrm{P}=0.06)$. Analysis of variance of raw data for disease scoring verified the existence of variability within the F1 generation; hence the significance level is very high for late leaf spot severity score. The disease severity score as well as the percentage of defoliation are relatively high with an average severity score of $6.06 \mathrm{on}$ the ICRISAT scale and $87.7 \%$ for the average percentage of defoliation. The highest percentage of defoliation is $91 \%$ with the cross SH470PxPC79-79; the lowest percentage of defoliation is $82 \%$ with the cross CN94CxNAMA (Table 3). PC79-79, GM656 then NAMA as well as most of the crosses that involve them have low severity score. In fact, several crosses involving on the one hand resistant parents and on the other hand sensitive (SH470P, AS, CN94C) and resistant parents (PC79-79, GM656, NAMA) were resistant. These crosses (PC7979xSH470P, GM656xAS, PC79-79xAS, ASxNAMA, ASxGM656, CN94CxPC79-79, ASxPC79-79, CN94CxNAMA, and SH470PxGM656) have been shown to be resistant to moderately resistant. Crosses involving resistant parents were all resistant.

There is a difference between the severity scores of the disease depending on the direction of crossing of our different lines. Disease severity scores are low when the female parent is resistant. When the female parent is sensitive disease severity scores are higher (table 4).

\section{Correlation between severity score and the} percent of defoliation due to late leaf spot

We notice that the crosses with the lowest severity scores do not necessarily have the lowest percentage of defoliation. The analysis of the correlation gives us an average coefficient Correlation of Pearson test indicate the existence of a positive correlation between the severity score and the percentage of defoliation of late leaf spot. The correlation coefficient is 0.51 with a probability of 0.0001 . 


\section{Analysis by the GRIFFING model}

\section{Analysis of the genetic effects of resistance}

The results of the analysis of variance associated with General Combining Ability (GCA), Specific Combining Ability (SCA) and Reciprocal Combining Effects (RCE) are reported in (Table 5). Analysis reveals a highly significant difference for GCA, SCA and RCE effects for late leaf spot severity score. The GCA variance /SCA variance ratio is greater than zero for the disease severity score and defoliation. GCA is preponderant to the SCA in the total variation for the two components of the resistance.

\section{Analysis by the HAYMAN model}

\section{Analysis of variance of the diallel tables}

The results of the analysis of variance test for the various HAYMAN terms are reported in (Table 6). The results of this analysis presented in this table, let see that they are similar to those obtained by the GRIFFING's model concerning the degree of significance of the additivity effects $(\mathrm{a}=\mathrm{GCA})$ and of the dominance effects $(b=S C A)$.

The "a" additivity and "b" dominance effects, which represent general (GCA) and specific (SCA) combination abilities, respectively, in HAYMAN show a highly significant difference in the genetic effects of resistance. The analysis revealed the existence of a highly significant difference in the effects of additivity "a" for the two resistance components according to the HAYMAN's model. The term "b1" which expresses the sense of dominance showed an insignificant difference for the two components. There is therefore a bidirectional dominance of genes.

The term "b2", which expresses the mean deviation of the hybrids from the mean values of their parents (gene distribution), is highly significant for the disease score. There is therefore an asymmetry in the distribution of genes showing dominance. For the percent defoliation trait, the b2 term is not significant. There is therefore no asymmetry in the distribution of genes showing dominance.

The term "b3", which is the portion of the deviation due to the dominance specific to each hybrid, represents the Specific Combining Ability itself (SCA). A highly significant difference is noted for the severity score of late leaf spot and non-significant for the percent defoliation.

The terms "c" and "d" which express maternal effects and reciprocity effects, respectively, were highly significant for the severity score of late leaf spot. For percent defoliation, these parameters showed no significant effect.

\section{Genetic parameters analysis}

The results of the estimation of the various genetic parameters attached to each component, analyse by HAYMAN method are presented in (Table 7).

The D-H1 expressions relating to the type of dominance are equal to 1.6 and 5.54 respectively for the severity score of the disease and the percent defoliation. Table 7 also gives the heritability for late leaf spot severity score and percent defoliation component both in the broad sense and in the narrow sense. The broad-sense heritability estimates for severity score is $90.2 \%$ and the narrow-sense heritability is $70.8 \%$, and the percent defoliation indicates broad-sense heritability of $39 \%$ and narrow-sense heritability of $40.6 \%$. We also note the average degree of dominance for the late leaf spot score, which is 0.84 , and for defoliation, it is 0.36 . The $\mathrm{D}-\mathrm{H} 1$ expressions being positive for both characters. 


\section{Graphical analysis}

Graphical analysis gives the graphical representation of $\mathrm{Wr}$ (covariance between parent $r$ and its descendants) as a function of $\mathrm{Vr}$ (variance of a parent $r$ and its descendants) relating to late leaf spot severity score. The figure shows the following three curves: the regression line $(\mathrm{Wr}=0.776 \mathrm{Vr}+0.41)$, the tangent to the parabola $(\mathrm{Wr} 1=1 \mathrm{Vr}+1.76)$ and the parabola $\mathrm{W} 2 \mathrm{r}=7.03 \mathrm{Vr}$. (FIGURE 2)

The slope of the regression line is greater than zero and close to $1(0.776 \sim 1)$, indicating that only additively acting and partially dominantly acting genes exist in parental combinations for late leaf spot resistance.

The additivity-dominance model is thus respected for this trait (severity score) of disease. The position of the parents in relation to $\mathrm{M}$ and $\mathrm{M}$ 'which are the points of intersection of the parabola and the regression line makes it possible to estimate the proportion of dominant and recessive genes. The two points correspond theoretically to the genotypes having respectively in the first, all the dominant genes and in the second, all the recessive genes controlling the trait. Parents CN94C and SH470P, located near M, concentrate in them a majority of dominant genes. Parents located midway between $\mathrm{M}$ and $\mathrm{M}$ 'have as many dominant as recessive genes. These are AS, NAMA, GM656 and PC79-79. The last three parents are characterized by their resistance to late leaf spot.

Genetic analysis of resistance to late leaf spot disease in peanuts has provided information on the nature of its heritability. In fact, on resistance to disease, we have studied two components associated with it; these are the disease severity score and the percent defoliation. From these analyzes, it appears that the disease severity score gives more information on disease resistance compared to the percent defoliation. Of our two complementary models used for the interpretation of the results obtained, such as Griffing and HAYMAN models; HAYMAN's model is much more strict; however, both models allowed us to obtain similar results and to be able to give an interpretation.

The results of the analysis of variance of F1 population show the existence of a very highly significant difference for the severity score of late leaf spot, and no significant for the percent defoliation. In fact, the analysis did not allow us to discriminate the thirty-six entries into groups in terms of the percent defoliation. This could be explained by the fact that the experiment was done in a real environment which favored the increased effect of the environment on percent defoliation. Defoliation was also calculated at the end of the vegetative cycle of plants, which could also explain the defoliation induced by senescence and disease. Indeed Taita et al., (2005) have shown that late leaf spots represent surface areas which considerably reduce the total photosynthetic surface area of the leaves. Also, these lesions constitute a stimulant for the area of abscission of the leaflet Wankhade, A. P et al., (2021).

The severity scores recorded are quite high and highly variable with averages over 6 on the ICRISAT scale. The site had been reported favorable for late leaf spot and which resulted in higher scores Neya, (2017). Late or early leaf spot is favored by high humidity and temperatures of $25{ }^{\circ} \mathrm{C}$ to $30^{\circ} \mathrm{C}$ KOITA K., (2013). Late leaf spot develops more in conditions with high relative humidity, allowing optimal development of the disease. NAMA, PC79-79 and GM656 recorded low scores confirming their resistance to late leaf spot. AS, CN94C and SH470P have confirmed their susceptibility to the disease. Crosses showing low severity scores indicate the 
possibility of using the varieties involved in these crosses for resistance improvement. The difference in severity observed according to the direction of crossing should be taken into account.

Results of the analysis related GCA, SCA and Reciprocal Combining Effects (RCE) were significant with both Griffing and HAYMAN models. This would indicate their involvement in the expression of resistance Minoungou A. (2006). The significance of GCA effects for the two components, severity score and percent defoliation by both models indicate strong additivity effects for these traits. The values of GCA variance on SCA variance ratio for the late leaf spot severity score indicate that additivity have a preponderant influence on the gene expression of this trait compared to the percent defoliation where the ratio is low. This would make this trait appear to be the first choice trait in the diallel analyzes for resistance. Pasupuleti et al., (2013) reported that disease score is the best selection criterion in the field for use in breeding programs due to its high heritability and ease of measurement. However, it would be essential to take defoliation into account in the choice of parents in breeding programs.

The significant SCA for the severity score of late leaf spot is an indication that in selection programs it would be wise to proceed with a rigorous choice of parents. We can then, in hybridization programs, take advantage of a specific cross to improve this trait in hybrids. The reciprocity effects (RCE) showed a nonsignificant difference in the percent defoliation indicating that we therefore do not have to worry about a maternal effect in improving this trait. It also reveals that the direction of crossbreeding has no effect on the performance of hybrids; therefore, a halfdiallel would be enough to select this trait.

Table.1 Characteristics of the peanuts varieties used in the diallel device.

\begin{tabular}{|c|c|c|c|c|}
\hline line & Origin & Botanical type & Cycle (days) & Late leaf spot \\
\hline GM656 & USA (Texas-AgriLife) & Spanish & 110 & resistant \\
\hline NAMA & Burkina Faso (Local) & Virginia & 110 & resistant \\
\hline PC79-79 & Sénégal (ISRA) & Spanish & 110 & resistant \\
\hline A.S & Burkina Faso (Local) & Spanish & 90 & susceptible \\
\hline SH470P & Burkina Faso (INERA) & Spanish & 90 & susceptible \\
\hline CN94C & Burkina Faso (INERA) & Spanish & 90 & susceptible \\
\hline
\end{tabular}

Table.2 Experimental crosses plan (30 crosses and 6 self-pollination)

\begin{tabular}{|c|c|c|c|c|c|c|}
\hline q0 & GM656 & NAMA & PC79-79 & A.S & SH470P & CN94C \\
\hline GM656(1) & 1X1 & $1 \mathrm{X} 2$ & $1 \mathrm{X} 3$ & $1 \mathrm{X} 4$ & $1 X 5$ & $1 \mathrm{X} 6$ \\
\hline NAMA(2) & $2 X 1$ & $2 \times 2$ & $2 \mathrm{X} 3$ & $2 X 4$ & $2 \times 5$ & $2 \times 6$ \\
\hline PC7979(3) & $3 \mathrm{X} 1$ & $3 X 2$ & $3 \times 3$ & $3 \mathrm{X} 4$ & $3 \times 5$ & $3 \times 6$ \\
\hline A.S $(4)$ & $4 X 1$ & $4 X 2$ & $4 \times 3$ & $4 X 4$ & $4 \times 5$ & $4 \times 6$ \\
\hline SH470P(5) & $5 X 1$ & $5 \times 2$ & $5 \times 3$ & $5 X 4$ & $5 X 5$ & $5 \times 6$ \\
\hline CN94C (6) & $6 \mathrm{X} 1$ & $6 \times 2$ & $6 \times 3$ & $6 X 4$ & $6 \times 5$ & $6 \times 6$ \\
\hline
\end{tabular}


Table.3 Performances of $36 \mathrm{~F} 1$ entries for late leaf spot score and percent defoliation.

\begin{tabular}{|c|c|c|c|c|c|}
\hline \multicolumn{3}{|c|}{ Late leaf spot Score } & \multicolumn{3}{|c|}{ Percent Defoliation } \\
\hline Entries & Mean & Group & Entries & Mean & Group \\
\hline CN94CxGM656 & 8,8 & A & SH470xPC79-79 & 91,00 & A \\
\hline SH470xCN94C & 8,8 & A & AS & 90,67 & A \\
\hline ASxCN94C & 8,8 & A & GM656 & 90,33 & A \\
\hline GM656xCN94C & 8,7 & A & NAMAxCN94C & 90,00 & A \\
\hline ASxSH470P & 8,7 & $\mathrm{~A}$ & PC79-79xSH470P & 90,00 & $\mathrm{~A}$ \\
\hline SH470xAS & 8,7 & A & SH470xAS & 90,00 & A \\
\hline SH470P & 8,7 & A & SH470xCN94C & 90,00 & A \\
\hline SH470xPC79-79 & 8,5 & $\mathrm{AB}$ & CN94CxSH470P & 89,67 & A \\
\hline NAMAxCN94C & 8,2 & $\mathrm{ABC}$ & SH470P & 89,67 & A \\
\hline SH470xNAMA & 8,0 & $\mathrm{ABC}$ & GM656xSH470P & 89,33 & A \\
\hline $\mathbf{A S}$ & 7,7 & $\mathrm{BCD}$ & NAMAxAS & 89,33 & A \\
\hline NAMAxSH470P & 7,5 & $\mathrm{CDE}$ & ASxCN94C & 89,00 & $\mathrm{~A}$ \\
\hline PC79-79xCN94C & 7,3 & CDEF & ASxSH470P & 89,00 & A \\
\hline CN94C & 7,3 & CDEF & CN94C & 88,67 & A \\
\hline CN94CxAS & 7,3 & CDEF & CN94CxAS & 88,67 & A \\
\hline CN94CxSH470P & 7,3 & CDEF & CN94CxGM656 & 88,67 & A \\
\hline GM656xSH470P & 7,0 & DEFG & SH470xNAMA & 88,67 & $\mathrm{~A}$ \\
\hline NAMAxAS & 6,7 & EFGH & PC79-79xAS & 88,33 & A \\
\hline GM656 & 6,5 & FGH & ASxGM656 & 88,00 & A \\
\hline PC79-79xSH470P & 6,3 & GH & CN94CxPC79-79 & 88,00 & A \\
\hline GM656xAS & 6,0 & $\mathrm{H}$ & GM656xCN94C & 87,33 & A \\
\hline PC79-79xAS & 6,0 & $\mathrm{H}$ & ASxNAMA & 87,00 & A \\
\hline ASxNAMA & 5,0 & $\mathrm{I}$ & GM656xAS & 87,00 & A \\
\hline ASxGM656 & 4,7 & IJ & NAMAxGM656 & 87,00 & A \\
\hline CN94CxPC79-79 & 4,3 & IJ & PC79-79xCN94C & 87,00 & A \\
\hline PC79-79xGM656 & 4,0 & JK & PC79-79xNAMA & 86,67 & A \\
\hline GM656xPC79-79 & 3,8 & JKL & ASxPC79-79 & 86,33 & A \\
\hline NAMAxPC79-79 & 3,3 & KL & NAMAxPC79-79 & 86,00 & A \\
\hline ASxPC79-79 & 3,2 & KL & SH470PxGM656 & 86,00 & A \\
\hline PC79-79xNAMA & 3,0 & $\mathrm{~L}$ & NAMAxSH470P & 85,67 & A \\
\hline CN94CXNAMA & 3,0 & $\mathrm{~L}$ & GM656xPC79-79 & 85,33 & A \\
\hline PC79-79 & 3,0 & $\mathrm{~L}$ & PC79-79xGM656 & 85,33 & A \\
\hline NAMA & 3,0 & $\mathrm{~L}$ & PC79-79 & 84,67 & A \\
\hline SH470PxGM656 & 3,0 & $\mathrm{~L}$ & GM656xNAMA & 84,33 & A \\
\hline GM656xNAMA & 3,0 & $\mathrm{~L}$ & NAMA & 83,67 & $\mathrm{~A}$ \\
\hline NAMAxGM656 & 3,0 & $\mathrm{~L}$ & CN94CxNAMA & 82,00 & A \\
\hline F Test & & & F Test & & \\
\hline SD & & & SD & & \\
\hline CV & & & $\mathbf{C V}$ & & \\
\hline Pro. & & & Pro. & & \\
\hline Average & & & Average & & \\
\hline
\end{tabular}

The means that share the same letters are not statistically different.

$\mathrm{SD}=$ Standard Deviation $-\mathrm{CV}=$ Coefficient of Variation 
Table.4 Severity of late leaf spot of a few crosses depending on the direction of crossing

\begin{tabular}{|c|c|c|c|}
\hline Cross $\delta^{\lambda} / q$ & Severity score & reciprocal cross & Severity score \\
\hline AS x PC79-79 & 3,1 & PC79-79 $\times$ AS & 6 \\
\hline CN94C x NAMA & 3 & NAMA x CN94C & 8.1 \\
\hline SH470P x GM656 & 3 & GM656 x SH470P & 7 \\
\hline
\end{tabular}

Table.5 Analysis of variance GCA, SCA and RCE by the GRIFFING method of the severity score of late leaf spot and the percent defoliation.

\begin{tabular}{|c|c|c|c|c|c|c|}
\hline \multirow{2}{*}{$\begin{array}{c}\text { Tested } \\
\text { effects }\end{array}$} & \multicolumn{2}{|c|}{ Mean square MS } & \multicolumn{2}{c|}{ Variance } & \multicolumn{2}{c|}{ F Test } \\
\cline { 2 - 7 } & $\begin{array}{c}\text { Severity } \\
\text { score }\end{array}$ & $\begin{array}{c}\text { Percent } \\
\text { Defoliation }\end{array}$ & $\begin{array}{c}\text { Severity } \\
\text { score }\end{array}$ & $\begin{array}{c}\text { Percent } \\
\text { Defoliation, }\end{array}$ & $\begin{array}{c}\text { Severity } \\
\text { score }\end{array}$ & $\begin{array}{c}\text { Percent } \\
\text { Defoliation }\end{array}$ \\
\hline GCA & 214,95 & 28,96 & 1,791 & 1,20 & $5,58^{*}$ & $5,37^{*}$ \\
\hline SCA & 69,37 & 5,39 & 1,285 & 0,89 & $8,4^{* *}$ & $0,72 \mathrm{~ns}$ \\
\hline RCE & 7,02 & 10,71 & & & $7,65^{* *}$ & $1,43 \mathrm{~ns}$ \\
\hline AGC / ASC & & & 1,40 & 1,34 & & \\
\hline
\end{tabular}

${ }^{*}, \mathrm{P}<0,05 ; * *, \mathrm{P}<0,01 ;{ }^{* * *}, \mathrm{P}<0,001 ; \mathrm{ns}, \mathrm{P}>0,05$, GCA :General Combining Ability, SCA :Specific Combining Ability, RCE :Reciprocal Combining Effects

Table.6 Analysis of variance of late leaf spot score and percent defoliation by the HAYMAN's model

\begin{tabular}{|c|c|c|c|c|c|c|c|}
\hline \multirow{2}{*}{$\begin{array}{c}\text { Source } \\
\text { of } \\
\text { variation }\end{array}$} & \multirow{2}{*}{$\begin{array}{l}\text { Meaning } \\
\text { (Tested } \\
\text { Effects) }\end{array}$} & \multicolumn{2}{|c|}{$\begin{array}{c}\text { Mean Square } \\
\text { MS }\end{array}$} & \multicolumn{2}{|c|}{ F-Probability } & \multicolumn{2}{|c|}{$\begin{array}{l}\text { Significant } \\
\text { importance }\end{array}$} \\
\hline & & $\begin{array}{l}\text { Severity } \\
\text { score }\end{array}$ & $\begin{array}{c}\text { Percent } \\
\text { Defoliation }\end{array}$ & $\begin{array}{l}\text { Severity } \\
\text { score }\end{array}$ & $\begin{array}{c}\text { Percent } \\
\text { Defoliation }\end{array}$ & $\begin{array}{c}\text { Severity } \\
\text { score }\end{array}$ & $\begin{array}{c}\text { Percent } \\
\text { Defoliation }\end{array}$ \\
\hline $\mathbf{A}$ & Additivity & 56,56 & 42,90 & 71,89 & 5,20 & $* *$ & $* *$ \\
\hline B & Dominance & 6,26 & 7,78 & 7,96 & 0,94 & $* *$ & Ns \\
\hline b1 & $\begin{array}{l}\text { Direction of } \\
\text { dominance }\end{array}$ & - & 0,98 & - & 0,12 & $\mathrm{Ns}$ & Ns \\
\hline b2 & $\begin{array}{l}\text { Direction of } \\
\text { gene } \\
\text { distribution }\end{array}$ & 4,92 & 13,43 & 6,25 & 1,63 & $* *$ & ns \\
\hline b3 & $\begin{array}{c}\text { Specific } \\
\text { Combining } \\
\text { Ability itself }\end{array}$ & 7,71 & 5,39 & 9,80 & 0,65 & $* *$ & ns \\
\hline C & $\begin{array}{l}\text { Average } \\
\text { maternal } \\
\text { effect }\end{array}$ & 12,62 & 7,52 & 16,04 & 0,91 & $* *$ & ns \\
\hline D & $\begin{array}{l}\text { Reciprocal } \\
\text { effects }\end{array}$ & 4,22 & 12,31 & 5,37 & 1,49 & $* *$ & ns \\
\hline
\end{tabular}


Table.7 Estimation of the different genetic parameters of the late leaf spot score and percent defoliation according to HAYMAN

\begin{tabular}{|c|c|c|c|c|}
\hline Genetics parameters & \multicolumn{2}{|c|}{ Lateleaf spot score } & \multicolumn{2}{c|}{ Percent defoliation } \\
\hline E : Environmental variance & Value & Standard deviation & Value & Standard deviation \\
\hline D : Additive effects & 0,42 & 0,07 & 2,74 & 0,47 \\
\hline H1 : Non additive effects & 5,73 & 1,45 & 6,38 & 4,8 \\
\hline H2 : Weighted non-additive effects & 4,13 & 1,43 & 0,84 & 5,42 \\
\hline F : Product of additive by dominance & 3,35 & 1,04 & 0,15 & 3,51 \\
\hline Mp: Parent average & 6,05 & 1,48 & 3,68 & 6,05 \\
\hline MF1: Average F1 & 6 & 0,27 & 87,9 & 0,69 \\
\hline H2b : Broad-sense heritability(\%) & 90,2 & 0,11 & 87,6 & 0,31 \\
\hline h2n : Narrow-sense heritability (\%) & 70,8 & 0,49 & 40,6 & 0,11 \\
\hline Sqr(H1/D) Average degree of dominance & 0,84 & 0,16 & 0,36 & 0,1 \\
\hline D-H1 : (type of dominance) & 1,6 Partial dominance & 5,54 Partial dominance \\
\hline
\end{tabular}

Fig.1 Map of experimental site and the climatic zone to which it belongs.

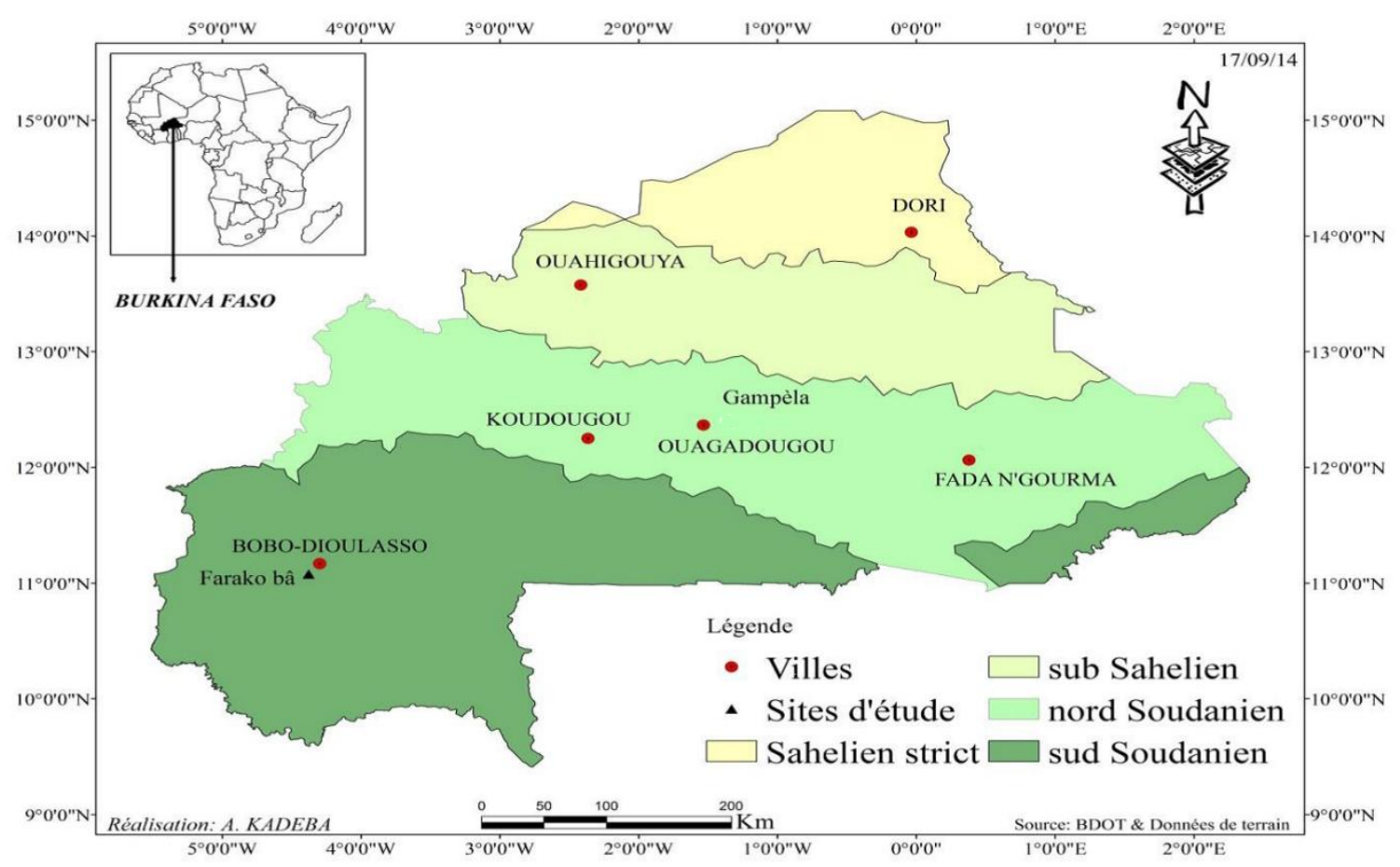

Fig.2 Graphical representation of Wr (covariance between parent $r$ and its descendants) versus $\mathrm{Vr}$ (variance of a parent $\mathrm{r}$ and its descendants) for late leaf spot resistance. 


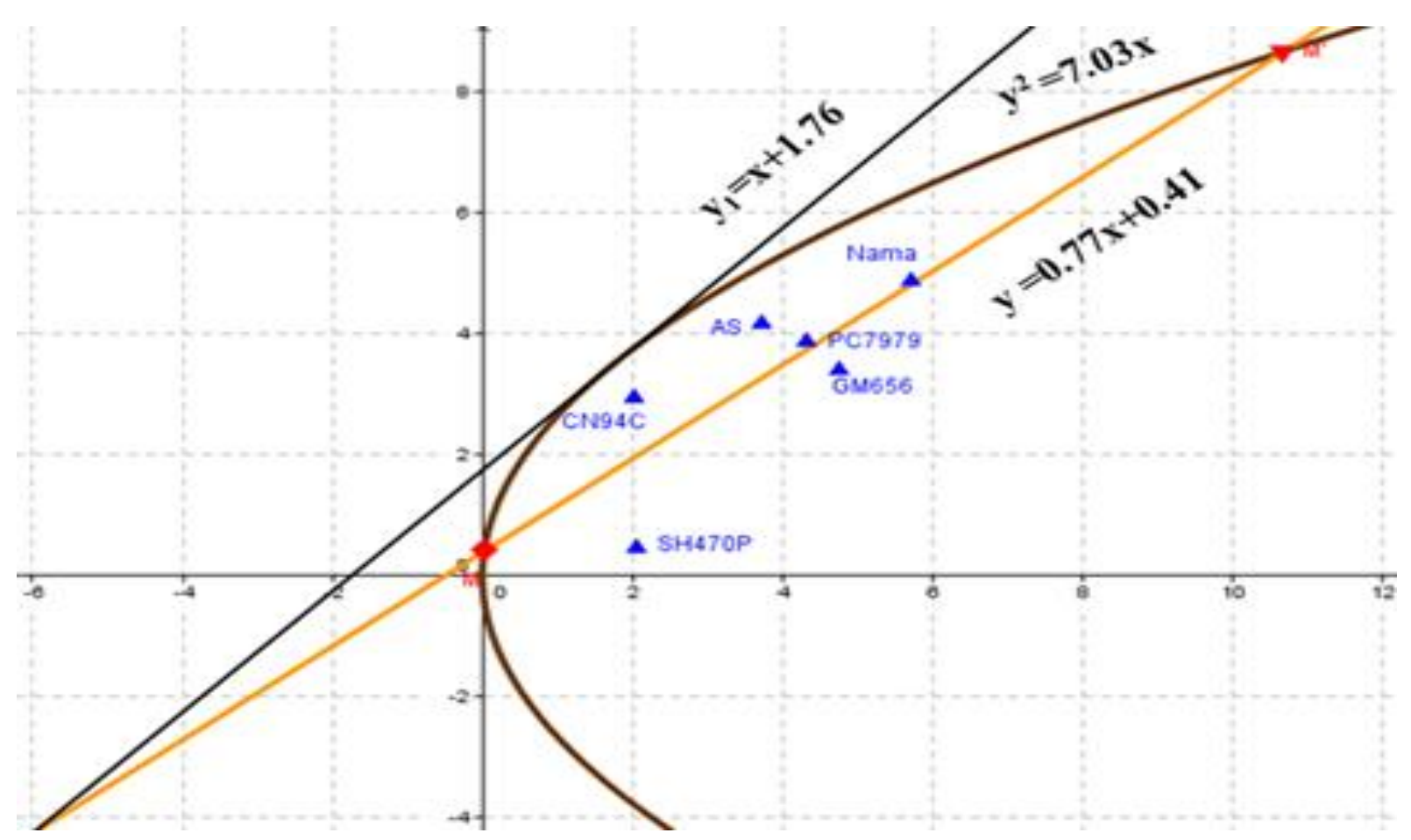

The results are however different for disease score, because the reciprocity effects (RCE) are highly significant, which indicates that the maternal effects are not insubstantial for this trait. Thus, any breeding program for late leaf spot resistance should take into account the direction of crossing. It would therefore be very helpful to use the resistance donor as the female parent to take advantage of the maternal effects of late leaf spot resistance. Heritability is a statistical data that assesses the role of genetic factors in the probability of the appearance of a phenotypic trait in a given population. High heritability guarantees a very high chance of transmitting genes. The results obtained in this study for late leaf spot score give a broad-sense heritability of $90.2 \%$ and a narrow-sense heritability of $70.8 \%$. The late leaf spot severity score better reflects disease resistance Subrahmanyam, P. et al., (1982); in this regard, it can be noted that it is found to be more heritable and could be a trait of choice in a breeding strategy for the improvement of resistance to late leaf spot. The heritability's calculated for percent defoliation trait give a broad-sense heritability of $39 \%$ and a narrow-sense heritability of $40.6 \%$. Working on heritability in peanut Anderson et al., (1991) showed that election based on defoliation would probably be most appropriate due to its high heritability. This heritability can be under influence. Indeed, phenotypic selection is based on the evaluation of genotypes in the field. This selection has two limits: the difficulty of appreciating the value of genotypes due to the existence of strong interactions between genotypes and the environment Chaudhari, S. et al., (2019) and ignorance of the genes involved. It is also known that heritability is the proportion of the phenotypic variance due to the genotypic variance.

The environment therefore has an impact on the expression of heritability. Minoungou (2006) in his work on the genetic determinism of resistance to early leaf spot, considered heritability rates ranging from 16.2 to $49.7 \%$ according to the Griffing method as being good enough to transmit the trait. 
These results show that the two characters studied in resistance to late leaf spot would be heritable. The zero effect of mean hybrid deviation compared to parental mean values indicates that dominance is bidirectional for both components. It can be said that the deviations due to the dominance of genes are not predominant in one direction.

This means that genes with opposite effects coexist in our parental genotypes. As the b2 term is significant for the disease severity score, the distribution of genes for late leaf spot resistance shows that there is an asymmetry, whish indicating that some parents have more dominant genes than others. The D-H1 expressions being positive for both characters. This indicates that the average dominance is of the "partial dominance" type.

Through graphical analyzes of $\mathrm{Wr}$ as a function of $\mathrm{Vr}$, we noticed that the parents NAMA, PC79-79 resistant to late leaf spot are located in the middle position between $\mathrm{M}$ and $\mathrm{M}$ '; which indicates that these parents have as many dominant as recessive genes. Based on these results, resistance to late leaf spot could arise from a complex of dominant genesrecessive genes.

The resistance traits are governed by the coexistence of dominant and recessive genes. Indeed, the points of intersection of the parabola with the regression line ( $\mathrm{M}$ and $\mathrm{M}$ ') characterize the genotypes respectively possessing all the dominant genes (weak $\mathrm{Wr}$ and $\mathrm{Vr}$ ) and all the recessive genes (strong $\mathrm{Wr}$ and Vr). MININGOU (2006), working on different isolates of Cercospora arachidicola and characters associated with resistance, found that resistance to early leaf spot was governed by additive recessive genes. Nevil, (1981) and Kornegay et al., (1980) also noted that resistance would be under the control of recessive genes
The "severity score" and "percent defoliation" components of late leaf spot resistance are polygenic traits. The severity score trait of disease operates under the influence of additivity and dominance of genes. The study also found that the severity score trait was very heritable and would better reflect resistance to the disease. The results obtained in this study for the severity score of late leaf spot give abroad-sense heritabilityof $90.2 \%$ and narrow-sense heritability of $70.8 \%$.

Some crosses such as, the entries SH470PxGM656, CN94CxNAMA, ASxPC79 -79, CN94CxPC79-79, ASxGM656, ASx NAMA, PC-7979xAS, GM656xAS, and PC7979xSH470Pshowed resistant to late leaf spot. Genotypes NAMA, PC79-79, GM656 could be recommended in hybridization programs aimed at improving resistance to late leaf spot. Access to the genome would undoubtedly allow a better understanding of the inheritance of genetic traits and could help improve the effectiveness of breeding programs by saving time and efficient results. It would be more appropriate to assess defoliation at different stages of disease. This will allow a better understanding of it heritability.

\section{Acknowledgements}

The authors would like to thank (FONERBurkina Faso) for funded this research, INERA/CREAF-Ouest directorate staff members and for their advising and support for this research.

\section{References}

Janila, P., Nigam, S. N., Pandey, M. K., Nagesh, P., and Varshney, R. K. (2013). Groundnut improvement: use of genetic and genomic tools. Front. Plant Sci. 25, 4a23. doi: 10.3389/fpls.2013.00023 
Chaudhari S, Khare D, Patil S C, Sundravadana S, Variath M T, Sudini H K, Manohar S S, Bhat R S and Pasupuleti J (2019) Genotype $\times$ Environment Studies on Resistance to Late Leaf Spot and Rust in Genomic Selection Training Population of Peanut (Arachis hypogaea L.). Front. Plant Sci. 10:1338. doi: 10.3389/fpls.2019.01338

Denwar, N. N.; Simpson, C. E.; Starr, J. L.; Wheeler, T. A.; Burow, M. D. Evaluation and Selection of Interspecific Lines of Groundnut (Arachis hypogaea L.) for Resistance to Leaf Spot Disease and for Yield Improvement. Plants 2021, 10, 873. https://doi.org/10.3390/ plants1005087

Wankhade, A. P.; Kadirimangalam, S. R.; Viswanatha, K. P.; Deshmukh, M. P.; Shinde, V. S.; Deshmukh, D. B.; Pasupuleti, J. Variability and Trait Association Studies for Late Leaf Spot Resistance in a Groundnut MAGIC Population. Agronomy 2021, 11, 2193. https:// doi.org/10.3390/agronomy1111219

Singh, M. P.; Erickson, J. E.; Boote, K. J.; Tillman, B. L.; Jones, J. W.; Van Bruggen, A. H. Late Leaf Spot Effects on Growth, Photosynthesis, and Yield in Peanut Cultivars of Differing Resistance. Agron. J. 2011, 103, 8591.

Subrahmanyam, P.; McDonald, D.; Waliyar, F.; Reddy, L. J.; Nigam, S. N.; Gibbons, R. W.; Rao, V. R.; Singh, A. K.; Pande, S.; Reddy, P. M.; et al., Screening Methods and Sources of Resistance to Rust and Late Leaf Spot of Groundnut. Information Bulletin no. 47 ; International Crops Research Institute for the Semi-Arid Tropics: Patancheru, India, 1995.

NEVIL D. J., 1981. Components of resistance to Cercospora arachidicola and
Cercosporidium personatum in groundnut. Ann. Aplli. Boil. 99: 77-86.

Pasupuleti, J., Ramaiah, V., Rathore, A. et al., Euphytica, $2013 \quad$ Phaeoisariopsis personata, Arachis hypogaea Inheritance Maternal effect Resistance breeding Groundnut 193: 13. doi :10.1007/s10681-013-0881-7

Faye, I. (2010) Contrôle génétique de la dormance des graines fraiches chez des variétés d'arachides (Arachis hypogaea L.) de type spanish et recherche de marqueur microsatellites liés au caractère. Thèse de docteur de troisième cycle Université Cheikh Anta Diop ; Dakar.

Griffing, B. (1956) Concept of general and specific combining ability in relation to diallel crossing system. Austr J. Biol. Sci. 9: 463-493.

Hayman, B. (1954) The theory and analysis of diallel crosses. Genetics; 39: 789-809.

Food and Agriculture Organisation of the United http://www.fao.org/pulses-2016/fr accessed 02 December 2021

Koita K., (2013) Tests de l'eactivité antifongique et analyse phytochimique des extraits de plantes locales du Burkina Faso pour le contrôle des maladies foliaires de l'arachide (Arachis hypogaea L.). Thèse de doctorat unique, Université de Ouagadougou; Ouagadougou.

Minoungou A., (2006) Contribution à l'étude de la résistance de quelques variétés d'arachide (Arachis hypogaea L.) à la cercosporiose précoce (due à Cercospora arachidicola Hori) et de son déterminisme génétique. Thèse de docteur ingénieur. Université de Cocody, Cocody.

Nevil D. J., (1981) Components of resistance to Cercospora arachidicola and Cercosporidium personatum in groundnut. Ann. Aplli. Boil. 99: 77-86. 
Neya B. F., (2017) Héritabilité de la résistance aux cercosporioses de l'arachide, (Arachis hypogaea L.) et de quelques caractères associés au rendement. Thèse de doctorat unique, Université OUAGA I Pr. Joseph KI-ZERBO; Ouagadougou.

Ouedraogo M., Smith O. D., Simpsom C. E., Smith D. H., (1994) Early and late leaf spot resistance and agronomic performance of nineteen interspecific derived peanut lines. Peanut Sci. 21:99:104

Shokes F. M., And Culbreath A. K., (1997) Early and late leaf spots. Compendium of Peanuts Diseases, 2nd Edition. APS Press, St. Paul, MN17-20.

Subrahmanyam P., Mc DONALD D., Gibbons
R. W., Nigam S. N. and Nevill D. J., (1982) Resistance to rust and late leaf spot disease in some genotypes of Arachis hypogaea L. Peanuts Science, 9, P. 6-10.

Taita P., Sankara P., Guinko S., (2005) Les cercosporioses de l'arachide : Evaluation de l'incidence de deux cercosporioses sur l'arachide. Fiche technique $n^{\circ} 5$, INERA/CRREA-Ouest (station de Farako-Bâ), B.P. 910, Bobo-Dioulasso.

Anderson W. F., Holbrook C. C., and Wynne J. C., (1991) Heritability and EarlyGeneration Selection for Resistance to Early and Late Leaf spot in Peanut; Crop Sci. 31:588-593.

\section{How to cite this article:}

Neya Bawomon Fidèle, Thio Ibié Gilles, Dabire Tobdem Gaston, Nana Toundwensida Abel, Koita Kadidia, Zagre M'BI Bertin and Sankara Philippe. 2021. Diallel Analysis of Severity Score and Defoliation Percent of Late Leaf Spot (Cercosporidium personatum) [Berk.and Curtis] Deighton]) on Peanut (Arachis hypogaea L). Int.J.Curr.Microbiol.App.Sci. 10(12): 283296. doi: https://doi.org/10.20546/ijcmas.2021.1012.033 